\title{
Expression of Myosin Heavy Chain Isoform mRNA Transcripts in the Masseter and Medial Pterygoid Muscles
}

\author{
Expresión de Transcripciones de ARNm de Isoforma de Cadena Pesada \\ de Miosina en los Músculos Masetero y Pterigoideo Medial
}

\author{
Neus Ciurana'; Rosa Artells $^{1}$; Aroa Casado ${ }^{1}$ \& Josep Maria Potau ${ }^{1}$
}

CIURANA, N.; ARTELlS, R.; CASADO, A. \& POTAU, J. M. Expression of myosin heavy chain isoform mRNA transcripts in the masseter and medial pterygoid muscles. Int. J. Morphol., 39(5):1406-1411, 2021.

SUMMARY: Both the masseter and medial pterygoid muscles elevate the mandible, raising the lower jaw by acting simultaneously on the lateral and medial surfaces of the mandibular ramus. Nevertheless, electromyographic studies indicate that these muscles, as well as the superficial and deep heads of the masseter, act in a different way during mastication. We have analyzed by real time quantitative polymerase chain reaction (RT-qPCR) the expression of myosin heavy chain (MHC) isoforms in the masseter and medial pterygoid muscles in humans in order to identify possible differences in the expression patterns that may be related to functional differences identified with electromyography. Our findings indicate that the expression pattern of MHC isoforms in the two muscles is characteristic of fast and powerful phasic muscles. We have also observed a high percentage of expression of the MHC-IIx isoform and the expression of the MHC-M isoform at the mRNA level in both muscles, an isoform that does not translate into protein in the masticatory muscles of humans. The high percentage of expression of the MHC-IIx isoform in humans can be related to a high contractile speed of the masseter and medial pterygoid in humans. On the other hand, the low percentage of expression of the MHC-M isoform at the mRNA level in both muscles can be related to the complex evolutionary process that has reduced the size and force of the masticatory muscles in humans.

KEY WORDS: Masseter; Medial pterygoid; Myosin heavy chain.

\section{INTRODUCTION}

The masseter and medial pterygoid are two important masticatory muscles that act directly on the ramus of the mandible to elevate it during chewing and biting (Taylor \& Vinyard, 2013). The masseter has a superficial head that arises from the zygomatic arch and inserts into the angle of the mandible and a deep head that also arises from the zygomatic arch and inserts in the lateral surface of the ramus of the mandible (Williams \& Warwick, 1980). The medial pterygoid muscle arises from the pterygoid fossa and inserts on the medial surface of the ramus and angle of the mandible (Williams \& Warwick). Its fibers are directed obliquely downward and backward, similar to those of the superficial head of the masseter. In humans, the masseter and medial pterygoid muscles are multipennate (Isola et al., 2018), with large physiological cross-sectional areas and high force production (Van Eijden et al., 1997; Horton et al., 2001; Taylor \& Vinyard).

Electromyographic studies have shown that both the masseter and medial pterygoid muscles help to elevate the mandible (Basmajian \& De Luca, 1985; Wood, 1987; Schindler et al., 2006), while the medial pterygoid also contributes to the protrusion of the mandible (Basmajian \& De Luca). Electromyographic studies have also identified functional differences in the superficial and deep heads of the masseter. The anterior region of the superficial head is activated mainly during vertical movements of the mandible, while the posterior part acts mainly to stabilize the temporomandibular joint (Blanksma et al., 1997; GuzmánVenegas et al., 2015). In contrast, the posterior region of the deep head of the masseter is activated during lateral and protrusion/retrusion movements of the mandible (Basmajian \& De Luca; Blanksma et al.).

The contractile properties of force, speed and resistance to fatigue in muscle fibers have been related to the expression pattern of myosin heavy chain (MHC) isoforms (Bottinelli \& Reggiani, 2000). The skeletal muscle of adult humans expresses the MHC-I, MHC-IIa and MHCIIx isoforms (Baldwin \& Haddad, 2001). The MHC-I isoform

\footnotetext{
${ }^{1}$ Unit of Human Anatomy and Embryology, Faculty of Medicine, University of Barcelona, C/Casanova 143, 08036 Barcelona, Spain. FUNDING. This study was supported by the Ministerio de Economía y Competitividad of Spain (project CGL2014-52611-C2-2-P to J.M.P.), by the European Union (FEDER), and by the Ajudes Predoctorals of the University of Barcelona (APIF-UB 2016/2017 to AC).
} 
is expressed in slow-oxidative fibers with a high resistance to fatigue and slow contractile speed. These fibers are predominant in tonic and postural muscles. The MHC-IIx isoform is expressed in fast-twitch glycolytic fibers with a high contractile speed and force production and a low resistance to fatigue. Finally, the MHC-IIa isoform is expressed in fast-twitch oxidative-glycolytic fibers, which have contractile characteristics between MHC-I and MHCIIx isoforms. The MHC-IIa and MHC-IIx isoforms are predominant in phasic muscles (Bottinelli et al., 1999; Pette \& Staron, 2000; Schiaffino \& Reggiani, 2011). Besides these three $\mathrm{MHC}$ isoforms, the masticatory muscles of non-human primates express MHC-M, a specialized MHC isoform (Rowlerson et al., 1983) that is associated with a moderate contractile speed (between MHC-I and MHC-IIa isoforms) and greater force (Hoh, 2002; Toniolo et al., 2008). The lack of the MHC-M isoform in humans is related to the inactivation of the MYH16 gene, which encodes the MHCMisoform, as the result of a frameshift deletion at codon 660 that led to a stop codon in the coding sequence (Stedman et al., 2004). Thus, part of this gene can be transcribed into mRNA, but the mRNA is not translated into protein. Stedman et al. estimated that this inactivation of MYH16 occurred approximately $2.4 \mathrm{Ma}$, before the appearance of the genus Homo, and they attributed the marked size reduction in human masticatory muscles to this inactivation. Perry et al. (2004) later analyzed a longer sequence of the MYH16 gene and postulated that the frameshift deletion occurred 5.3 Ma, at the time of the chimpanzee-human divergence.

Type-I, -IIa and -IIx muscle fibers express only the MHC-I, MHC-IIa and MHC-IIx isoforms, respectively (Sciote et al., 1994; Sciote \& Morris, 2000), while hybrid muscle fibers generally express more than one type of MHC isoform (Korfage et al., 2005; Pette \& Staron). Several studies using ATPase and immunohistochemistry (IHC) have quantified these types of muscle fibers in the masseter and medial pterygoid muscles of humans. Shaughnessy et al. (1989) used ATPase staining to analyze the masseter muscle and the medial pterygoid muscle of humans and found $57 \%$ of type-I fibers and $43 \%$ of type-II fibers in the masseter and $50.4 \%$ of type-I fibers and $49.6 \%$ of type-II fibers in the medial pterygoid. Korfage et al. (2000) and Korfage \& Van Eijden (2000) used IHC to analyze the two muscles and found $26.8 \%$ of type-I, $9.8 \%$ of type-IIa, $19.3 \%$ of typeIIx, and $44.1 \%$ of hybrid fibers in the superficial head of the masseter; $47.8 \%$ of type-I, $6.4 \%$ of type-IIa, $5.4 \%$ of type-IIx, and $40.4 \%$ of hybrid fibers in the deep head of the masseter; and $32.2 \%$ of type-I, $5.4 \%$ of type-IIa, $10.6 \%$ of type-IIx, and $51.8 \%$ of hybrid fibers in the medial pterygoid.

In the present study, we have quantified the percentages of mRNA expression of the MHC isoforms by real-time quantitative polymerase chain reaction (RT-qPCR) in the anterior and posterior regions of the superficial and deep heads of the masseter and in the medial pterygoid in modern humans. We have analyzed the three main MHC isoforms that are present in these muscles at both the mRNA and protein levels (MHC-I, MHC-IIa y MHC-IIx) (Baldwin $\&$ Haddad). Also, we have included the MHC-M isoform, which is also present only at the mRNA - but not the protein - level due to its importance in the evolution of the human masticatory muscles (Stedman et al.). Although the expression of MHC isoforms has been studied in the masticatory muscles by ATPase staining and IHC, no studies have analyzed this expression by RT-qPCR. RT-qPCR allows the direct quantification of the percentages of expression of each isoform at the mRNA level, so the results are not affected by the presence of hybrid fibers. Our main objective was to obtain molecular information on the functional characteristics of the masseter and medial pterygoid in humans in order to identify differences between the two heads of the masseter and the medial pterygoid that could be related to the functional differences identified by electromyography. In addition, we reasoned that the use of RT-qPCR would allow us to compare our results with those obtained by other authors using different techniques.

\section{MATERIAL AND METHOD}

Muscle samples. We dissected the right masseter and medial pterygoid muscles of ten humans. The samples came from cadavers donated to the Body Donation Service of the School of Medicine, University of Barcelona, Spain. There were five males and five females, with a mean age of 72.3 years (range, 31-94). The cadavers were kept at $4^{\circ} \mathrm{C}$ for $24-48$ hours after death and then frozen at $-18^{\circ} \mathrm{C}$ until dissection.

The same investigator dissected all samples. The adipose and conjunctive tissues were removed to isolate the superficial and deep heads of the masseter muscle and the medial pterygoid muscle (Fig. 1). Each of the muscles was weighed on a precision scale and $0.5 \mathrm{~cm}^{3}$ samples of the anterior and posterior regions of each head of the masseter and of the medial pterygoid were obtained and immediately frozen in saline solution at $-18{ }^{\circ} \mathrm{C}$ until the time of the molecular analysis.

RNA isolation and cDNA synthesis. The RNA from the muscle samples was extracted using the commercial RNeasy mini kit (Qiagen, Valencia, CA) according to the manufacturer's protocol. We used a NanoDrop 1000 Spectrophotometer to determine the concentration, purity and amount of RNA and TaqMan Reverse Transcription Reagent Kit (Applied Biosystems, Foster City, CA) to synthesize 

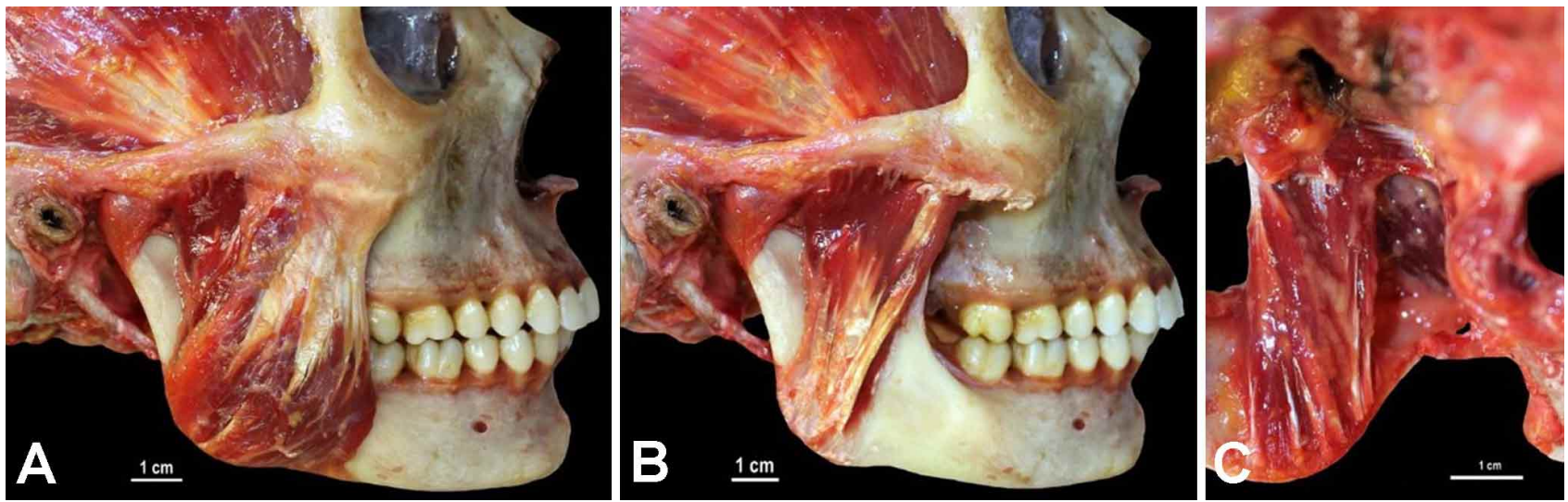

Fig. 1 Dissection of (a) the superficial head of the masseter muscle,(b) the deep head of the masseter muscle, and (c) the medial pterygoid muscle.

cDNA. We performed reverse transcription using $330 \mathrm{ng}$ of total RNA in $10 \mu \mathrm{l}$ of RT Buffer, $22 \mathrm{ml}$ of $25 \mathrm{mM}$ magnesium chloride, $20 \mu \mathrm{l}$ dNTPs, $5 \mu$ l Random Hexamers, $2 \mu$ RNAse Inhibitor, $2.5 \mu$ MultiScribe Reverse Transcription and RNA sample plus RNAse-free water, for a final volume of $100 \mu \mathrm{l}$, in the following thermal cycler conditions: $10 \min 25^{\circ} \mathrm{C}, 48$ $\min 30^{\circ} \mathrm{C}$ and $5 \min 95^{\circ} \mathrm{C}$.

Gene expression and quantification by RT-qPCR. Applied Biosystems supplied primers and probes. Primers are labeled at the 5' end with the reporter dye molecule FAM. MYH-I (Hs00165276_m1), MYH-IIa (Hs00430042_m1), MYH-IIx (Hs00428600_m1) and MYH-IIM (Hs01385213_m1) genes were analyzed. In order to avoid any possible effects of postmortem mRNA degradation, the mRNA values for each of the $\mathrm{MHC}$ isoforms were normalized using the reference gene ACTB (Bustin et al., 2009). The mRNA of ACTB is detectable for more than 22 days post-mortem in skeletal muscle fibers preserved at $4^{\circ} \mathrm{C}$ (Bahar et al., 2007), and it is one of the reference genes that is least affected by muscular degeneration (Yüzbasioglu et al., 2010).

We performed RT-qPCR in a total volume of $20 \mu \mathrm{l}$ in the ABI Prism 7700 Sequence Detection System (Applied Biosystems) using the following master mix conditions: $10 \mu \mathrm{l}$ of the TaqMan Universal PCR Master Mix, $1 \mu \mathrm{l}$ of the primers and probes, $2 \mu \mathrm{l}$ of the cDNA and $7 \mu \mathrm{l}$ of the RNAse-free water. We ran all samples for each gene in duplicate using the following thermal cycler conditions: $2 \mathrm{~min} 50^{\circ} \mathrm{C}, 10 \mathrm{~min} 95$ ${ }^{\circ} \mathrm{C}$ and 40x ( $\left.15 \mathrm{~s} 95^{\circ} \mathrm{C}, 1 \mathrm{~min} 60^{\circ} \mathrm{C}\right)$. We used genomic DNA as negative control in each run. We captured fluorescent emission data and quantified mRNA concentrations by using the critical threshold value and $2-\Delta \Delta \mathrm{Ct}$.

Finally, we calculated the percentage of expression of each MHC isoform relative to the total expression of all MHC isoforms (\%MHC-I, \%MHC-IIa, \%MHC-IIx and \%MHC-M).
Statistical analyses. The non-parametric Mann-Whitney test was used to compare the expression patterns of the MHC isoforms in the different muscles. We used SPSS Statistics 22 for all statistical analyses and set statistical significance at $\mathrm{P} \leq 0.05$.

Ethical note. The study was approved by the Institutional Review Board (or Ethics Committee) of the University of Barcelona (protocol code 00003099, 18 September 2017).

\section{RESULTS}

Our results (Table I) indicate that the masseter and medial pterygoid have an expression pattern of MHC isoforms characteristic of phasic muscles, with a percentage of expression of the MHC-I isoform of $28.6 \%$ in the masseter and $29.6 \%$ in the medial pterygoid, and a percentage of expression of the MHC-IIx isoform of $26.4 \%$ in the masseter and $28.6 \%$ in the medial pterygoid. In both muscles and in both heads of the masseter, the expression pattern was the same (\%MHC-IIa > \% MHC-I > \% MHC-IIx > \% MHC-M) (Table I), while in the posterior region of the superficial head of the masseter, it was \%MHC-IIa $>\%$ MHC-IIx $>\%$ MHCI $>\%$ MHC-M (Table I). In all cases, we observed mRNA transcripts of the MHC-M isoform (12.1\% in the superficial head of the masseter, $9.9 \%$ in the deep head of the masseter and $11.3 \%$ in the medial pterygoid).

There were no significant differences in the expression pattern of the MHC isoforms between the masseter and the medial pterygoid muscles, between the two heads of the masseter muscle, or between the anterior and the posterior regions of the superficial and the deep heads of the masseter (Table II). 
Table I. Meanand standard deviations (in parentheses) of weight in grams and percentages of expression of MHC isoforms in the masseter and medial pterygoid muscles.

\begin{tabular}{lccccc}
\hline \multicolumn{1}{c}{ Muscle } & Weight & \%MHC-I & \%MHC-IIa & \%MHC-IIx & \%MHC-M \\
\hline Masseter & $17.8(5.0)$ & $28.6(3.7)$ & $34.0(7.7)$ & $26.4(5.5)$ & $11.0(9.5)$ \\
Superficial head & $13.2(3.4)$ & $28.3(4.4)$ & $31.9(9.0)$ & $27.8(7.0)$ & $12.1(9.4)$ \\
$\quad$ Anterior region & & $29.7(7.1)$ & $32.7(9.8)$ & $26.8(8.8)$ & $10.9(11.8)$ \\
$\quad$ Posterior region & & $26.9(3.6)$ & $31.0(9.8)$ & $28.8(5.7)$ & $13.3(8.5)$ \\
Deep head & $4.6(2.1)$ & $28.9(4.3)$ & $36.2(7.9)$ & $25.0(6.4)$ & $9.9(9.9)$ \\
$\quad$ Anterior region & & $28.3(5.0)$ & $37.9(11.6)$ & $22.9(9.4)$ & $10.9(10.5)$ \\
$\quad$ Posterior region & & $29.4(4.3)$ & $34.6(7.4)$ & $27.0(8.3)$ & $9.0(9.9)$ \\
Medial pterygoid & $7.6(2.7)$ & $29.6(2.5)$ & $30.4(6.0)$ & $28.6(7.3)$ & $11.3(9.7)$ \\
\hline
\end{tabular}

Table II. Means, standard deviations (in parentheses) and P-values for the comparison of percentages of expression of MHC isoforms in the masseter and medial pterygoid muscles.

\begin{tabular}{|c|c|c|c|c|}
\hline & $\%$ MHC-I & \%MHC-IIa & $\%$ MHC-IIx & $\% \mathrm{MHC}-\mathrm{M}$ \\
\hline Masseter & $28.6(3.7)$ & $34.0(7.7)$ & $26.4(5.5)$ & $11.0(9.5)$ \\
\hline Medial pterygoid & $29.6(2.5)$ & $30.4(6.0)$ & $28.6(7.3)$ & $11.3(9.7)$ \\
\hline $\mathrm{P}$ & 0.684 & 0.105 & 0.436 & 1.000 \\
\hline Superficial head of the masseter & $28.3(4.4)$ & $31.9(9.0)$ & $27.8(7.0)$ & $12.1(9.4)$ \\
\hline Deep head of the masseter & $28.9(4.3)$ & $36.2(7.9)$ & $25.0(6.4)$ & $9.9(9.9)$ \\
\hline $\mathrm{P}$ & 0.796 & 0.247 & 0.280 & 0.631 \\
\hline $\begin{array}{l}\text { Anterior region of the superficial head of the } \\
\text { masseter }\end{array}$ & $29.7(7.1)$ & $32.7(9.8)$ & $26.8(8.8)$ & $10.9(11.8)$ \\
\hline $\begin{array}{l}\text { Posterior region of the superficial head of the } \\
\text { masseter }\end{array}$ & $26.9(3.6)$ & $31.0(9.8)$ & $28.8(5.7)$ & $13.3(8.5)$ \\
\hline $\mathrm{P}$ & 0.315 & 0.529 & 0.393 & 0.393 \\
\hline Anterior region of the deep head of the masseter & $28.3(5.0)$ & $37.9(11.6)$ & $22.9(9.4)$ & $10.9(10.5)$ \\
\hline Posterior region of the deep head of the masseter & $29.4(4.3)$ & $34.6(7.4)$ & $27.0(8.3)$ & $9.0(9.9)$ \\
\hline $\mathrm{P}$ & 0.684 & 0.796 & 0.684 & 0.739 \\
\hline
\end{tabular}

\section{DISCUSSION}

We have found that both the masseter and the medial pterygoid muscles in humans have an MHC expression pattern characteristic of phasic muscles (Schiaffino \& Reggiani). This pattern is to be expected in muscles that act directly on the mandibular ramus to elevate the mandible for fast and powerful chewing (Basmajian \& De Luca; Schindler et al.). In addition, mRNA transcripts of the MHC-M isoform were present in all the muscles analyzed, although this isoform is not translated into protein (Stedman et al.). The absence of the MHC-M isoform at the protein level in human masticatory muscles has been related to their smaller size and lower capacity of force production in comparison with the masticatory muscles of non-human primates (Stedman et al.). This process of reduction of the masticatory apparatus that characterizes the evolution of Homo sapiens is reflected in our results in a lower degree of expression of the MHC-M isoform at the mRNA level when compared with other hominoid primates. A previous study by our group (Ciurana et al., 2017) found that MHCMhad a higher percentage of expression in chimpanzees, both in the masseter (11\% in humans vs. $37.2 \%$ in chimpanzees) and in the medial pterygoid $(11.3 \%$ in humans vs. $37.7 \%$ in chimpanzees), while the \%MHCIIx, an isoform related to high contractile speed, was significantly higher in humans than in chimpanzees both for the masseter $(26.4 \%$ in humans vs. $12.8 \%$ in chimpanzees) and the medial pterygoid (28.6\% in humans vs. $11.8 \%$ in chimpanzees). Longer muscle fibers have also been associated with greater contractile speed and the human masseter muscle fibers are longer than those of chimpanzees (Taylor \& Vinyard). We can therefore observe that throughout the process of evolution, humans have lost capacity of force production but gained contractile speed in their muscles of mastication.

The expression pattern of the MHC isoforms was similar in the masseter and the medial pterygoid muscles (Table II). Electromyographic studies have also found that the two muscles have a similar form of action during the elevation of the mandible in humans (Basmajian \& De 
Luca; Schindler et al.). Nevertheless, electromyographic studies (Basmajian \& De Luca; Blanksma et al.) have also reported functional differences between the superficial and the deep head of the masseter. The superficial head is an important elevator of the mandible, while the deep head participates in lateralization of the mandible and in repositioning the temporomandibular joint. However, these functional differences between the two heads of the masseter are not reflected in the expression of MHC isoforms in humans (Table II). Similarly, the functional differences between the anterior and posterior regions of the masseter muscle observed in electromyographic studies (Blanksma et al.; Guzmán-Venegas et al.) are not reflected in the percentage of expression of MHC isoforms found in our study (Table II).

Our findings on the expression of the MHC isoforms differ widely from those of another study using ATPase (Shaughnessy et al.), in which the human masseter and medial pterygoid muscles had more than $50 \%$ of type-I fibers, while we have observed only $28.6 \%$ of MHC-I expression in the masseter and $29.6 \%$ in the medial pterygoid. These discrepancies may be the result of hybrid fibers present in the ATPase-based study. In contrast, studies using IHC found $26.8 \%$ of type-I fibers in the superficial head of the masseter and $32.2 \%$ in the medial pterygoid (Korfage \& Van Eijden; Korfage et al., 2000), which is in line with our findings $(28.3 \%$ MHC-I in the superficial head of the masseter and $29.6 \%$ MHC-I in the medial pterygoid). However, our results are different from those obtained by IHC in the deep head of the masseter (Korfage \& Van Eijden; Korfage et al., 2000), where $47.8 \%$ of typeI fibers were identified, while we observed a percentage of expression of the MHC-I isoform of $28.9 \%$.

In summary, we found no differences in expression of the MHC isoforms in humans between the masseter and the medial pterygoid muscles, indicating that the two muscles work together to elevate the mandible (Basmajian \& De Luca), nor did we find differences between the superficial and deep heads of the masseter and their anterior and posterior regions. These results contrast with the different functions of the heads of the masseter reported in electromyographic studies (Blanksma et al.; GuzmánVenegas et al.). In addition, we observed that MHC-M isoform is expressed at the mRNA level in humans, but this isoform presents significantly lower expression levels than those observed in chimpanzees (Ciurana et al.). This finding is not surprising given what is known about the inactivation of the MYH16 gene and the reduction of the size of the muscles of mastication that have occurred throughout human evolution (Stedman et al.). In contrast, the MHC-IIx isoform is expressed at a higher percentage in humans than in chimpanzees (Ciurana $e t a l$.) and this result can be related to the longer muscle fibers observed in the masseter in humans with respect to chimpanzees (Taylor \&Vinyard) and to the development of a greater contractile speed of the masticatory muscles in Homo sapiens, possibly due to the development of speech.

\section{ACKNOWLEDGEMENTS}

We would like to thank Manuel Martín, Sebastián Mateo, and Pau Rigol (Body Donation Service, University of Barcelona) for their support and collaboration and Renee Grupp for assistance in drafting the manuscript. This study was supported by the Ministerio de Economía y Competitividad of Spain (project CGL2014-52611-C2-2P to J.M.P.), by the European Union (FEDER), and by the Ajudes Predoctorals of the University of Barcelona (APIFUB 2016/2017 to AC).

CIURANA, N.; ARTELLS, R.; CASADO, A. \& POTAU, J. M. Expresión de transcripciones de ARNm de isoforma de cadena pesada de miosina en los músculos masetero y pterigoideo medial. Int. J. Morphol., 39(5):1406-1411, 2021.

RESUMEN: Los músculos masetero y pterigoideo medial elevan la mandíbula actuando de forma simultánea sobre las caras lateral y medial de su rama. Sin embargo, los estudios electromiográficos indican que estos dos músculos actúan de forma diferente durante la masticación, de la misma forma que lo hacen las porciones superficial y profunda del músculo masetero. En el presente estudio hemos analizado mediante PCR en tiempo real la expresión de las isoformas de la cadena pesada de la miosina o myosin heavy chain (MHC) en los músculos masetero y pterigoideo medial en humanos, con la finalidad de identificar diferencias en los patrones de expresión que se puedan relacionar con las diferencias funcionales identificadas con la electromiografía. Nuestros resultados indican que el patrón de expresión de las isoformas de la MHC en los dos músculos es la característica de los músculos rápidos y potentes. También hemos observado un elevado porcentaje de expresión de la isoforma MHC-IIx y la expresión a nivel de ARNm de la isoforma MHC-M en los dos músculos, una isoforma que no se detecta a nivel de proteína en los músculos masticadores humanos. El elevado porcentaje de expresión de la isoforma MHC-IIx que hemos observado se puede relacionar con una elevada velocidad de contracción de los músculos masetero y pterigoideo medial en los humanos. Por otro lado, el bajo porcentaje de expresión de la isoforma MHC-M a nivel de ARNm en ambos músculos se puede relacionar con los procesos evolutivos complejos que han reducido el tamaño y la fuerza de los músculos masticadores en los humanos.

PALABRAS CLAVE: Músculo masetero; Músculo pterigoideo medial; Cadena pesada de la miosina. 


\section{REFERENCES}

Bahar, B.; Monahan, F. J.; Moloney, A. P.; Schmidt, O.; MacHugh, D. E.\& Sweeney, T. Long-term stability of RNA in post-mortem bovine skeletal muscle, liver and subcutaneous adipose tissues. BMC Mol. Biol., 8(1):108, 2007.

Baldwin, K. M. \& Haddad, F. Effects of different activity and inactivity paradigms on myosin heavy chain gene expression in striated muscle. J. Appl. Physiol., 90(1):345-57, 2001.

Basmajian, J. V. \& de Luca, C. J. Muscles alive. Their functions revealed by electromyography. Baltimore, Williams and Wilkins, 1985.

Blanksma, N. G.; Van Eijden, T. M. G. J.; Van Ruijven, L. J.\& Weijs, W. A. Electromyographic heterogeneity in the human temporalis and masseter muscles during dynamic tasks guided by visual feedback. J. Dent. Res., 76(1):542-51, 1997.

Bottinelli, R.; Pellegrino, M. A.; Canepari, M.; Rossi, R. \& Reggiani, C. Specific contributions of various muscle fibre types to human muscle performance: an in vitro study. J. Electromyogr. Kinesiol., 9(2):8795, 1999.

Bottinelli, R. \& Reggiani, C. Human skeletal mucle fibres: molecular and functional diversity. Prog. Biophys. Mol. Biol., 73(2-4):195-262, 2000

Bustin, S. A.; Benes, V.; Garson, J. A.; Hellemans, J.; Huggett, J.; Kubista, M.; Mueller, R.; Nolan, T.; Pfaffl, M. W.; Shipley, G. L.; Vandesompele, J.\& Wittwer, C. T. The MIQE guidelines: minimum information for publication of quantitative real-time PCR experiments. Clin. Chem., 55(4):611-22, 2009.

Ciurana, N.; Artells, R.; Muñoz, C.; Arias-Martorell, J.; BelloHellegouarch, G.; Pérez-Pérez, A.; Pastor, J. F.\& Potau, J. M. Expression of MyHC isoforms mRNA transcripts in different regions of the masseter and medial pteygoid muscles in chimpanzees. Arch. Oral Biol., 83:63-67, 2017.

Guzmán-Venegas, R. A.; Picand, J. L. \& de la Rosa, F. J. Functional compartmentalization of the human superficial masseter muscle. PLoS One, 10(2):e0116923, 2015.

Hoh, J. F. Y. 'Superfast' or masticatory myosin and the evolution of jawclosing muscles of vertebrates. J. Exp. Biol., 205(Pt 15):2203-10, 2002.

Horton, M. J.; Brandon, C. A.; Morris, T. J.; Braun, T. W.; Yaw, K. M. \& Sciote, J. J. Abundant expression of myosin heavy-chain IIB RNA in a subset of human masseter muscle fibres. Arch. Oral Biol., 46(11):1039-50, 2001

Isola, G.; Anastasi, G. P.; Matarese, G.; Williams, R. C.; Cutroneo, G.; Bracco, P. \& Piancino, M. G. Functional and molecular outcomes of the human masticatory muscles. Oral Dis., 24(8):1428-41, 2018.

Korfage, J. A.; Brugman, P. \& Van Eijden, T. M. Intermuscular and intramuscular differences in myosin heavy chain composition of the human masticatory muscles. J. Neurol. Sci., 178(2):95-106, 2000.

Korfage, J. A. \& Van Eijden, T. M. Myosin isoform composition of the human medial and lateral pterygoid muscles. J. Dent.Res., 79(8):1618$25,2000$.

Korfage, J. A.; Koolstra, J. H.; Langenbach, G. E. J. \& Van Eijden, T. M. G. J. Fiber-type composition of the human jaw muscles-(part 2) Rol of hybrid fibers and factors responsible for inter-individual variation. J. Dent.Res., 84(9):784-93, 2005.

Perry, G. H.; Verrelli, B. C. \& Stone, A. C. Comparative analyses reveal a complex history of molecular evolution for human MYH16. Mol. Biol. Evol., 22(3):379-82, 2004

Pette, D. \& Staron, R. S. Myosin isoform, muscle fiber type, and transitions. Microsc. Res. Tech., 50(6):500-9, 2000.

Rowlerson, A.; Mascarello, F.; Veggetti, A. \& Carpenè, E. The fibre-type composition of the first branchial arch muscles in Carnivora and Primates. J. Muscle Res. Cell Motil., 4:443-72, 1983.

Schiaffino, S. \& Reggiani, C. Fiber types in mammalian skeletal muscles. Physiol. Rev., 91(4):1447-1531, 2011.
Schindler, H. J.; Rues, S.; Türp, J. C. \& Lenz, J. Heterogeneous activation of the medial pterygoid muscle during simulated clenching. Arch. Oral Biol., 51(6):498-504, 2006.

Sciote, J.; Rowlerson, A. M.; Hopper, C. \& Hunt, C. P. Fibre type classification and myosin isoforms in the human masseter muscle. $J$. Neurol. Sci., 126(1):15-24, 1994.

Sciote, J. J. \& Morris, T. J. Skeletal muscle function and fibre types: the relationship between occlusal function and the phenotype of jawclosing muscles in human. J. Orthod., 27(1):15-30, 2000.

Shaughnessy, T.; Fields, H. \& Westbury, J. Association between craniofacial morphology and fiber-type distribution in human masseter and medial pterygoid muscles. Int. J. Adult Orthodon. Orthognath. Surg., 4(3):145-55, 1989.

Stedman, H. H.; Kozyak, B. W.; Nelson, A.; Thesier, D. M.; Su, L. T.; Low, D. W.; Bridges, C. R.; Shrager, J. B.; Minugh-Purvis, N. \& Mitchell, M. A. Myosin gene mutation correlates with anatomical changes in the human lineage. Nature, 482 (6981):415-8, 2004.

Taylor, A. B. \& Vinyard, C. J. The relationships among jaw-muscle architecture, jaw morphology, and feeding behavior in extant apes and modern humans. J. Phys. Anthropol., 151(1):120-34, 2013.

Toniolo, L.; Cancellara, P.; Maccatrozzo, L.; Patruno, M.; Mascarello, F. \& Reggiani, C. Masticatory myosin unveiled: first determination of contractile parameters of mucle fibers from carnivore jaw muscle. Am. J. Physiol. Cell Physiol., 295(6):C1535-42, 2008.

Van Eijden, T. M. G. J.; Korfage, J. A. M. \& Brugman, P. Architecture of the human jaw-closing and jaw-opening muscles. Anat. Rec., 248:46474, 1997.

Williams, P. \& Warwick, R. Gray's anatomy. Edinburgh, Churchill Livingstone, 1980.

Wood, W. W. A review of masticatory muscle function. J. Prosthet. Dent., 57(2):222-32, 1987.

Yüzbasıglu, A.; Onbas, 1lar, I.; Kocaefe, Ç. \& Özgüç, M. Assessment of housekeeping genes for use in normalization of real time PCR in skeletal muscle with chronic degenerative changes. Exp. Mol. Pathol., $88(2): 326-9,2010$

\author{
Corresponding author: \\ Josep Maria Potau MD, PhD \\ Unit of Human Anatomy and Embryology \\ Faculty of Medicine \\ University of Barcelona \\ C/Casanova 143 \\ 08036 Barcelona \\ SPAIN
}

E-mail: jpotau@ub.edu

Received: 18-06-2021

Accepted: 27-07-2021 